DOI: https://doi.org/10.32839/2304-5809/2021-5-93-68

УДК 342.7

Юрченко Є.О., Тадика Є.Д.

Національний юридичний університет імені Ярослава Мудрого

\title{
ТОРГІВЛЯ ЛЮДЬМИ ЯК СУЧАСНА ФОРМА РАБСТВА
}

\begin{abstract}
Анотація. Стаття присвячена висвітленню однієї з актуальних проблем людства - торгівлі людьми. Торгівля людьми є глобальною проблемою, і країни у всьому світі об'єднали зусилля та вибудували стратегії боротьби з цим явищем. Хоча рабство і торгівля рабами були давно скасовані, у багатьох частинах світу тривожно зростають нові та більш витончені форми рабства. Серед них торгівлю людьми визначають сучасною формою рабства. Поняття "торгівля людьми» визначається як міжнародними нормативно-правовими документами, так і законодавством України. Наведено визначення "торгівля людьми» із різних нормативно-правових актів. Здійснено аналіз статистичних даних розповсюдження цього явища в Україні. Розглянуто внутрішні й зовнішні чинники, які є причиною торгівлі людьми. Визначено основні елементи торгівлі людьми. Визначено позитивні і негативні зобов'язання держави у сфері протидії торгівлі людьми. Здійснено дослідження проблеми торгівлі людьми в контексті статті 4 Конвенції про захист прав людини і основоположних свобод. Загалом дотепер Свропейським Судом винесено лише 12 рішень по суті за статтею 4 Конвенції в контексті протидії саме торгівлі людьми.
\end{abstract}

Ключові слова: торгівля людьми, рабство, примусова праця, експлуатація, примус.

Yurchenko Elizaveta, Tadyka Egor

Yaroslav Mudryi National Law University

\section{HUMAN TRAFFICKING AS A MODERN FORM OF SLAVERY}

Summary. The article is devoted to one of the current problems of mankind - human trafficking. Trafficking in human beings is a global problem, and countries around the world have joined forces and developed strategies to combat it. Although slavery and the slave trade have long since been abolished, new and more sophisticated forms of slavery are growing alarmingly in many parts of the world. Among them, human trafficking is defined as a modern form of slavery. The concept of "trafficking in human beings" is defined both by international legal documents and the legislation of Ukraine. The definition of "human trafficking" from various regulations is given. The analysis of statistical data on the spread of this phenomenon in Ukraine is carried out. A study of the problem of trafficking in human beings in the context of Article 4 of the Convention for the Protection of Human Rights and Fundamental Freedoms. Internal and external factors that cause human trafficking are considered. The main elements of human trafficking are identified, including: treatment of a person as a commodity that is bought and sold; involvement in forced labor; meager wages or no wages at all; close supervision of the person; restriction of movement; use of violence and / or threat of its use; unsatisfactory living and working conditions. The positive and negative obligations of the state in the field of combating human trafficking have been identified. Article 4 of the Convention is formulated as a negative obligation to refrain from acts that may qualify as enslavement, enslavement or the involvement of a person in forced or compulsory labor. The positive commitments include: the introduction of an appropriate legal framework that would prohibit and punish trafficking in human beings; ensuring effective investigation of human trafficking; taking specific measures to protect existing or potential victims; ensuring an effective trial, which, however, is not an absolute obligation to pass a specific sentence. In total, so far the European Court has delivered only 12 judgments on the merits under Article 4 of the Convention in the context of combating trafficking in human beings.

Keywords: human trafficking, slavery, forced labor, exploitation, coercion.

Постановка проблеми. На сьогодні одним

1 із найгірших явищ, які існують у сучасному світі є торгівля людьми. Це явище, яке порушуе права людини, принижуе їі честь та гідність. Впродовж останніх років під впливом процесу глобалізації невпинно зростають масштаби торгівлі людьми. Суспільна небезпечність торгівлі людьми полягає в посяганні на невід'ємні права людини - право на повагу, на свободу та особисту недоторканність, свободу пересування і вільний вибір місця проживання, а інколи і право на життя. Торгівля людьми не оминула жодну країну світу. На жаль, не стала винятком і Україна. Кількість осіб, яким Мінсоцполітики встановлено статус особи, яка постраждала від торгівлі людьми у 2021 році станом на 09.03.2021 р. - 12 осіб. І3 них в трудову експлуатацію потрапило 2 особи, сексуальну - 1 , жебрацтво - 1, використання у збройних конфліктах -8 осіб. За оцінками Представництва Міжнародної організації 3 мі- грації (МОМ) в Україні, понад 230000 українців постраждали від торгівлі людьми, починаючи з 1991 року, що робить Україну однією з основних країн походження постраждалих від сучасного рабства в Європі. Більшість постраждалих, які протягом останніх років отримали допомогу від MOM, - молодь до 35 років. 60\% постраждалих від торгівлі людьми, які звернулися по допомогу до МОМ у 2016 році, - чоловіки, понад 80\% постраждалих мають вищу або технічну освіту. Наймолодшій постраждалій було 3 роки, а найстаршій - 83. Попри статистику оцінити реальні масштаби торгівлі людьми в Україні та світі важко, ураховуючи доволі високий рівень латентності цих злочинів.

Аналіз останніх досліджень і публікацій. Останнім часом через значне поширення проблеми торгівлі людьми їй почили приділяти значну увагу у засобах масової інформації, а також у науковій спільноті. Зокрема, праці щодо проб- 
леми торгівлі людьми присвятили А.В. Войціховський, 3.Р. Кісіль, О.М. Обушенко, О.В. Святун та інші.

Виділення не вирішених раніше частин загальної проблеми. Більша частина науковців у своїх працях акцентує увагу на кримінально-правовому аспекті торгівлі людьми, і майже жоден 3 них не розглядає проблему торгівлі людыми в аспекті захисту прав і свобод людини, а саме в контексті статті 4 Конвенції про захист прав людини і основоположних свобод (далі Конвенції).

Мета статті. Головною метою цієї роботи є висвітлення проблеми торгівлі людьми в контексті статті 4 Конвенції про захист прав людини і основоположних свобод.

Виклад основного матеріалу. Торгівля людьми вперше привернула увагу наприкінці 1980-х років. На початку XXI століття це було визнано серйозною глобальною проблемою, яка потребує глобальних рішень. Міжнародне співтовариство не має єдиного визначення поняття «торгівля людьми». Історично склалося так, що торгівля людьми визначалася як торгівля жінками та дітьми для проституції чи інших "аморальних цілей". Термін торгівля людьми визначений, як законодавством України, так і міжнародними договорами. Так, стаття 149 Кримінального кодексу України визначає торгівлю людьми як вербування, переміщення, переховування, передача або одержання людини, вчинені з метою експлуатації, з використанням примусу, викрадення, обману, шантажу, матеріальної чи іншої залежності потерпілого, його уразливого стану або підкупу третьої особи, яка контролює потерпілого, для отримання згоди на його експлуатацію [1].

Дещо відмінне визначення містить Закон України «Про протидію торгівлі людьми», а саме торгівля людьми визначається як здійснення незаконної угоди, об'єктом якої є людина, а так само вербування, переміщення, переховування, передача або одержання людини, вчинені з метою експлуатації, у тому числі сексуальної, 3 використанням обману, шахрайства, шантажу, уразливого стану людини або із застосуванням чи погрозою застосування насильства, з використанням службового становища або матеріальної чи іншої залежності від іншої особи, що відповідно до Кримінального кодексу України визнаються злочином [2].

Відповідно до Конвенції Ради Свропи про заходи щодо протидії торгівлі людьми, «торгівля людьми» означає найм, перевезення, передачу, приховування або одержання осіб шляхом погрози або застосування сили чи інших форм примусу, насильницького викрадення, шахрайства, обману, зловживання владою або безпорадним станом або наданням чи отриманням плати чи вигоди для досягнення згоди особи, яка має владу над іншою особою, для експлуатації. Експлуатація включає в себе, принаймні, експлуатацію проститущії інших осіб чи інші форми сексуальної експлуатації, примусову працю чи послуги, рабство чи подібну до рабства практику, поневолення або вилучення органів [3].

Згідно з Протоколом про запобігання і припинення торгівлі людьми, особливо жінками й дітьми, і покарання за неї, що доповнюе Кон- венщію Організащії Обєеднаних Націй проти транснаціональної організованої злочинності, «торгівля людьми» означає здійснювані з метою експлуатації вербування, перевезення, передачу, приховування або одержання людей шляхом загрози силою або їі застосування або інших форм примусу, викрадення, шахрайства, обману, зловживання владою або уразливістю положення або шляхом підкупу, у вигляді платежів або вигоди, для одержання згоди особи, яка контролюе іншу особу [4].

Незважаючи на глобальну проблему торгівлі людьми, вона не згадуеться у Конвенції, зокрема, в статті 4, яка забороняе «рабство», «підневільний стан» і «примусову чи обов'язкову працю». Жоден з пунктів статті 4 Конвенції не має звичного нам терміну «торгівля людьми». Проте Конвенція є живим інструментом, який тлумачиться Судом у світлі умов сьогодення. Саме принцип динамічного тлумачення Конвенції дозволив Суду 2010 року дійти висновку щодо того, що торгівля людьми в сучасному розумінні підпадае під заборону статті 4 Конвенції. Не дивно, що заборона торгівлі людьми не знайшла свого відображення в Конвенції, адже вона з'явилася під впливом Загальної декларації прав людини, прийнятої Генеральною Асамблеєю ООН в 1948 рощі, яка також прямо не згадує торгівлю людьми. В статті 4 Декларації міститься положення про заборону «рабства и работоргівлі у всіх її видах» [5].

Так, у своєму рішенні у справі Ранцев проти Кіпра та Росії, Свропейський суд 3 прав людини зазначив, що не може бути жодного сумніву в тому, що торгівля людьми загрожуе людській гідності і основним свободам її жертв і що іï не можна вважати сумісною 3 демократичним суспільством і цінностями, проголошеними в Конвенції. 3 огляду на свій обов'язок тлумачити Конвенцію у світлі сучасних умов, Суд не вважає за необхідне визначати, чи мало поводження, про яке йдеться у скарзі заявника, ознаки "рабства", "підневільного стану» чи "примусової та обов'язкової праці». Натомість Суд доходить висновку, що торгівля людьми як така, у значенні пункту «а» статті 3 Палермського протоколу та пункту «а» статті 4 Конвенції про заходи щодо протидії торгівлі людьми, підпадає під дію статті 4 Конвенції [5].

Європейський суд вважає, що торгівля людьми за своїм характером та цілями експлуатації заснована на здійсненні атрибутів права власності над людиною. При торгівлі людьми до людини відносяться як до товару, який підлягає купівлі-продажу і може бути підданий примусовій праці, часто за невеликі кошти або, взагалі, безоплатно в будь-якій сфрері. Вона передбачає чіткий нагляд за діяльність потерпілих, переміщення яких найчастіше $є$ обмеженим. Також торгівля людьми пов'язана 3 використанням насильства або погроз застосування такого насильства по відношенню до потерпілих. Автори пояснювального звіту до Конвенції Ради Свропи про заходи щодо протидії торгівлі людьми визначили торгівлю людьми як сучасний вираз світової работоргівлі. Варто зазначити, що відмінною рисою торгівлі людьми є те, що згода жертви торгівлі людыми на навмисну експлуатащію не має ніякого значення, якщо було використано 
будь-який засіб примусу з тих, що перераховані в Палермському протоколі.

Отже для торгівлі людьми властиві такі елементи:

- поводження 3 людиною, як 3 товаром, який купляеться і продається;

- залучення до примусової праці;

- мізерна оплата праці або взагалі їі відсутність;

- пильний нагляд за людиною; обмеження пересування;

- застосування насильства та/або погрози його застосування;

- незадовільні умови життя та праці.

Для вирішення проблеми торгівлі людьми варто з'ясувати першопричини, які призвели до торгівлі, іх умовно можна поділити на внутрішні та зовнішні.

До внутрішніх чинників належать:

1. низький рівень життя в порівнянні з іншими країнами;

2. низький рівень соціального запезпечення;

3. девіантна поведінка членів сім'ї (вживання алкоголю, наркотичних речовин тощо);

4. викривлення або відсутність моральних цінностей;

5. привабливість кращого життя за кордоном.

До зовнішніх чинників торгівлі людьми належать наступні:

1. лояльність іноземного законодавства до заняття проституцією;

2. попит на комерційну сексуальну експлуатацію;

3. попит на працю в галузях, де основна частина населення не бажає працювати через низку причин, зокрема небезпечні умови праці тощо.

Стаття 4 Конвенщії сорормульована як негативне зобов'язання утримуватись від дій, що можуть бути кваліфіковані як утримання у рабстві, підневільному стані або залучення особи до примусовоі чи обов’язкової праці. Проте Конвенція поклика- на надавати не лише теоретичний або ілюзорний захист, а повинна бути реальна та едективна на практиці. Для забезпечення реальної протидії торгівлі людьми, забороненої статтею 4 Конвенціï, не завжди достатньо лише виконання негативного обов'язку. У деяких випадках від держави вимагається вжиття активних дій з метою забезпечення цієї вкрай важливої для сучасних демократій заборони. До позитивних зобов'язань належать, зокрема: запровадження заходів, спрямованих на покарання торгівців, а також заходів, спрямованих на запобігання такій торгівлі, і заходів, спрямованих на захист потерпілих; запровадження належної нормативно-правової бази, яка б забороняла і карала такі діяння; забезпечення належної підготовки працівників державних правоохоронних і імміграційних служб; забезпечення ефрективного захисту від діянь, що підпадають під статтю 4 Конвенщї; вжиття конкретних заходів для захисту наявних або потенційних потерпілих; забезпечення ефективного судового розгляду, який, утім, не є абсолютним зобов'язанням щодо винесення конкретного вироку [7].

Висновки і пропозиції. Підсумовуючи вищезазначене, слід ще раз наголосити, що торгівля людьми $є$ реальною проблемою XXI століття, і стала сучасною формою рабства. На держави покладено обов'язок запровадження заходів, спрямованих на покарання торгівців, запобігання торгівлі людьми та захист потерпілих. 3 огляду на масштаби проблеми торгівлі людьми доцільно доповнити статтю 4 Конвенції частиною 4 у наступній редакції: «Нікого не може бути завербовано, переміщено, передано, переховано або одержано шляхом загрози силою чи їі застосування або інших форм примусу, викрадення, шахрайства, обману, зловживання владою або уразливістю положення, або шляхом підкупу, у вигляді платежів чи вигод, для одержання згоди особи, яка контролюе іншу особу».

\section{Список літератури:}

1. Кримінальний кодекс України : Кодекс України; Кодекс, Закон від 05.04.2001 № 2341-III // База даних «Законодавство України» / Верховна Рада України. URL: https://zakon.rada.gov.ua/go/2341-14 (дата звернення: 05.05.2021).

2. Про протидію торгівлі людьми : Закон України від 20.09.2011 № 3739-VI // База даних «Законодавство України» / Верховна Рада України. URL: https://zakon.rada.gov.ua/go/3739-17 (дата звернення: 05.05.2021).

3. Конвенція Ради Європи про заходи щодо протидії торгівлі людьми: Конвенція; Рада Європи від 16.05.2005 // База даних «Законодавство України» / Верховна Рада України. URL: https://zakon.rada.gov.ua/go/994_858 (дата звернення: 05.05.2021).

4. Протокол про попередження і припинення торгівлі людьми, особливо жінками і дітьми, і покарання за неї, що доповнюе Конвенцію Організації Об'єднаних Націй проти транснаціональної організованої злочинності (укр/рос): Протокол; ООН від 15.11.2000 // База даних «Законодавство України» / Верховна Рада України. URL: https://zakon.rada.gov.ua/go/995_791 (дата звернення: 05.05.2021).

5. Ранцев проти Кіпра та Pociï. URL: https://hudoc.echr.coe.int/app/conversion/pdf/?library=ECHR\&id=001109639\&filename=CASE $\% 200 F \% 20$ RANTSEV\%20v.\%20CYPRUS\%20AND\%20RUSSIA $\% 20-\% 20[$ Russian $\% 20$ Translation].pdf

6. Загальна декларація прав людини (рос/укр) : Декларація; ООН від 10.12.1948 // База даних «Законодавство України» / Верховна Рада України. URL: https://zakon.rada.gov.ua/go/995_015 (дата звернення: 05.05.2021).

7. Практика Свропейського суду з прав людини за статтею 4 Конвенції про захист прав людини і основоположних свобод. Київ : Видавництво «Фенікс», 2020. 48 с.

\section{References:}

1. Kriminal'nij kodeks Ukraini [Criminal Code of Ukraine]: Code of Ukraine; Code, Law of 05.04.2001 № 2341-III // Database "Legislation of Ukraine" / The Verkhovna Rada of Ukraine. URL: https://zakon.rada.gov.ua/go/2341-14 (accessed 05 May 2021).

2. Pro protidiyu torgivli lyud'mi [On combating human trafficking]: Law of Ukraine of 20.09.2011 № 3739-VI // Database "Legislation of Ukraine" / The Verkhovna Rada of Ukraine. URL: https://zakon.rada.gov.ua/go/3739-17 (accessed 05 May 2021). 
3. Konvenciya Radi Evropi pro zahodi shchodo protidii torgivli lyud'mi [Council of Europe Convention on Action against Trafficking in Human Beings]: Convention; Council of Europe dated 16.05.2005 // Database "Legislation of Ukraine" / The Verkhovna Rada of Ukraine. URL: https://zakon.rada.gov.ua/go/994_858 (accessed 05 May 2021).

4. Protokol pro poperedzhennya i pripinennya torgivli lyud'mi, osoblivo zhinkami i dit'mi, i pokarannya za nei, shcho dopovnyue Konvenciyu Organizacii Ob'ednanih Nacij proti transnacional'noi organizovanoi zlochinnosti [Protocol to Prevent, Suppress and Punish Trafficking in Persons, Especially Women and Children, supplementing the United Nations Convention against Transnational Organized Crime (UK / Russian)]: Protocol; UN dated 15.11.2000 // Database "Legislation of Ukraine" / The Verkhovna Rada of Ukraine. URL: https://zakon.rada.gov.ua/ go/995_791 (accessed 05 May 2021).

5. Case of Rantsev v. Cyprus and Russia (2010). URL: https://hudoc.echr.coe.int/app/conversion/pdf/?library= ECHR\&id=001-109639\&filename=CASE\%20OF\%20RANTSEV\%20v.\%20CYPRUS\%20AND\%20RUSSIA\%20-\%20 [Russian\%20Translation].pdf

6. Zagal'na deklaraciya prav lyudini [Universal Declaration of Human Rights]: Deklaraciya; OON vid 10.12.1948 // Baza danih «Zakonodavstvo Ukraini» / Verhovna Rada Ukraini. URL: https://zakon.rada.gov.ua/ go/995_015 (accessed 05 May 2021).

7. Praktika Evropejs'kogo sudu z prav lyudini za statteyu 4 Konvencii pro zahist prav lyudini i osnovopolozhnih svobod [The case law of the European Court of Human Rights under Article 4 of the Convention for the Protection of Human Rights and Fundamental Freedoms]. Kyiv: Feniks, 2020. 48 p. 